\title{
Arbitration: Understanding It in Theory and Indonesian Practice
}

\author{
Maskun*, Achmad, Naswar, Fauziah P. Bakti, Amaliyah \\ Faculty of Law, Hasanuddin University, Indonesia. \\ * Corresponding author's e-mail: maskun@unhas.ac.id
}

\section{ARTICLE INFO}

Keywords:

Arbitration; Cross-border

Transactions; Islamic Law

How to cite:

Maskun., Achmad., Naswar.,

Bakti, F.P., and Amaliyah.

(2019). “Arbitration: Under

standing It in Theory and

Indonesian Practice,"

Hasanuddin Law Review,

5(2): $220-234$

DOI:

10.20956/halrev.v5i2.1945

\begin{abstract}
Cross-border transactions have always attracted legal risks. Crossborder legal issues are emerging as a separate area of commercial risk that needs to be more precisely identified and better managed. Many cases of injury to multinational companies which would formerly have been pursued as a diplomatic claim by the nation state of the company are now resolved by arbitration between the company and the respondent state. Arbitration is one of dispute settlement bodies to resolve some issues particular trade, business, investment, and financial issues. Those issues are shaping the range and significance of the cross-border legal issue. Those issues also become a crucial issue to be dealt with the arbitral institution. The reason why the parties of contract choose arbitration is because of the place of arbitration, neutrality, confidentiality, cost and speed, recognition and enforcement of arbitral awards, refusing of arbitral awards, a model of arbitration, and arbitration institution. Those reasons are assumed also to be enacted in Indonesian arbitration practice and in the Islamic law.
\end{abstract}

Copyright $\odot 2019$ HALREV. All rights reserved.

\section{Introduction}

Cross-border transactions have always attracted legal risks. What has changed is the volume and range of international commerce in which almost all countries are involved and the complexity and significance for those countries of the legal issues that this commerce generates. Cross-border legal issues are emerging as a separate area of commercial risk that needs to be more precisely identified and better managed. ${ }^{1}$ Therefore, to overcome some problems arises in the area of the cross-border transaction (international business), some alternative dispute is offered to handle it such as negotiation, mediation, and arbitration. However, some businessperson assumes that

\footnotetext{
1 See the Australian Law Reform Commission, 1999, “International Arbitration, ALRC. 80, p2.
} 
both negotiation and mediation are often not the solution. The most reliable approaches to the issue of dispute resolution are arbitration.

In the context of legal issues of commerce, there are at least two matters which are relevant and which, to some extent, overlap. These are speed and cost. These considerations are generally very important in assessing a dispute resolution. ${ }^{2}$ In large part, for example, mediation developed in the United States (U.S) in response to the slow speed of dispute resolution by litigation and in particular, its high cost. Even though speed and cost matters are more appropriate to be applied in mediation and negotiation pursuant to some expert, ${ }^{3}$ arbitration has also its own argumentation to be said as less expensive and less time-consuming. In this context, arbitration offers some opportunity for flexibility and the parties may agree to reduce or dispense with the discovery of documents; to reduce or eliminate pleadings; to impose strict time limits, and to dispense with a hearing and have arbitration on documents alone. ${ }^{4}$

Arbitration basically is known also in Indonesia arbitration practice through Indonesia National Board of Arbitration and Indonesia Muamalat Board of Arbitration. Both arbitration institutions take responsibility to cover all arbitration matters and practices in Indonesia. In the area of the Islamic law, it is only emphasized in the area of Family Law. The term of Arbitration in it is known as "Tahkim". Even though the scope of the arbitration is limited to the family law, it does not mean that arbitration in the Islamic Law can not cover the area of commerce. The reason of it is because development of arbitration and most of the parties (clients) is Islamic people (Muslims). In the development of it, therefore, the Islamic law acknowledges the existence of arbitration in a broad sense covering the family law and commerce. This paper, therefore, will focus on the area of arbitration as one of alternative disputes resolution particular in Indonesian arbitration practice and the Islamic Law.

\section{Arbitration in Broad Context}

\subsection{Meaning of arbitration}

Arbitration is defined as a private method of settling commercial disputes. Arbitration as a concept is basically known as the large majority of the legal system, but it is different from one country to another in practice. Indeed, those state practices reflect problems and sometimes are applied approach differently in entire legal systems. ${ }^{5}$ Even though in terms of the legal system the approach is different, the concept of arbitration generally is quite the same. As can be seen, disputes in international business become the area of contracting parties to choose the best alternative dispute settlement to deal with the parties contract problems. ${ }^{6}$

In line with dispute settlement matters, legal infrastructure is needed by arbitration to fulfill its function. Indeed, the arbitral process intends to lead to a binding determination of a dispute. It means that in order to be binding, the law must support the agreement

\footnotetext{
2 Michael Pryles, Assesing Dispute Resolutin Prosedures, Course Materials of International Commercial Arbitration, Australia: UNSW - Sydney, 1997, p105.

3 Michael Pryles, Note 2.

4 Michael Pryles, Note 2.

5 See Mauro Rubino-Sammartono. International Arbitration: Law, and Arbitration, Netherland: Kluwer Law International, 2010, p1. see also A. Cavanna. History of Modern Law in Europe, Milan,1997, p490.

6 Mohammad Naqib Ishan Jan and Abdulrashid Lawana Haruna, 2014, "The Role of Arbitration in the Resolution of Internationa Commercial Disputes", IIUM Law Journal, 22 (2), p267.
} 
to arbitrate, the arbitral procedures, the determination of substantive liabilities and crucially, and the enforcement of the arbitral award.

Arbitration plays an important role in handling some international business cases. Historically, It has a long history in the international community. It can be seen for example that Bahrain has international commercial arbitration center long before those center existed in Paris and London as the modern era of international arbitration. ${ }^{7}$ It can be said, however, that it has similarity perilous course between arbitration in practice in some countries either in western countries or in eastern countries. Some nations, then, have granted a right to arbitration, usually in relation to actions of public authorities and through International Centre for the Settlement of Investment Disputes (ICSID). Most of these rights are under bilateral investment protection treaties.

The drawing of arbitration position (meaning) briefly as explained above-put arbitration in a good position rather than mediation or a court as a media to settle the dispute. Arbitration tends to be chosen by the merchants because the decision of the court only will be "final" or "enforceable" if there is no "appeal". If it is, it may take some time (time-consuming). The position of the court decision is quite the same as the decision or resolution of mediation. The decision of mediation is only resolved if the parties agree on terms of the settlement. If they fail to agree the dispute is not resolved.

Another critic is that a domestic court generally is a lack of judges who have competency or specialized in the area of international commercial law. ${ }^{8}$ The effect of it, the decision of the judges will be "appalled" by the parties because they are no satisfied with the decision. In this situation, it can be said that litigation (court) will not be either quick of cheap.

\subsection{The reason to choose arbitration}

Merchants (international businessman) today usually desire a quick resolution of the differences and preferably a decision that will not destroy business relationship amongst them. For this reason, the arbitration process poses these criteria. ${ }^{9}$ The process, of course, is voluntary in the sense that the parties agree to resolve their differences in this manner at the time that they enter into a contractual agreement when a dispute arises. ${ }^{10}$ It means that the parties show their autonomy to choose the law that governs their arbitration in the event of a dispute.

In line with the state practice in arbitration matters, the globalization of international commercial activities has improved the importance of arbitration as an alternative dispute settlement. ${ }^{11}$ It has tremendous growth in recent decades and shows the reason why the parties tend to choose it rather than court adjudication. ${ }^{12}$ According to Buhring-

\footnotetext{
7 Charles N. Brower and Jeremy K. Sharpe, 2003, "International Arbitration and the Islamic World: the Third Phase", the American of International Law, 97, July, p643. See also Hassan Ali Radhi, 1992, "State Courts and Arbitration in the Gulf Cooperation Councils (GCC) Countries", ICC Int'l Ct. Arb. Bull, 57 (5), p1.

8 Julian DM. Lew, Applicable Law in International Commercial Arbitration, Netherlands: Sijthoff and Noordhoff, 1978, p1.

9 John H. Willes and John A. Willes, Q.C. International Business Law: Environments and Transactions, Singapore: McGraw-Hill International Edition, 2005, p571.

10 John H. Willes and John A. Willes, Note 9, p.572.

11 Jelena Hrle, International Arbitration and Competition Law, Thesis, Faculty of Law, Canada: McGill University, 1999, p7.

12 Jelena Hrle, Note 11, p10.
} 
Uhle ${ }^{13}$, the benefits of arbitration are:14 Forum is neutral; Treaties ensure enforcement abroad; Confidentiality procedure; Forum has expertise; No appeal; Limited discovery; Less time consuming; More amicable; the Greater degree of voluntary compliance; Procedure is less costly; and Results are more predictable.

The relevant point of views further stated by Jelena Hrle. She states the reason why the contracting parties to choose arbitration, as followings: 15
"...the first place is the parties enjoy considerable control over arbitration proceedings.
The choose arbitrators, place, time and language of arbitration along with the procedural and substantive laws applicable. The second place is arbitration provides the most confidential method of resolving disputes. Most of the awards remain unpublished and, in matters concerning the claims based on the infringements of competition law, confidentiality is of immense importance. The third place is arbitration proceedings offer less formal setting judicial courtrooms thereby fostering good business relations upon the completion of the arbitration. The last is arbitration provides a neutral forum that presents significant advantages in international business as it avoids all the disadvantages associated with litigation in a foreign jurisdiction..."

According to Jonathan Hill 16 , the reason of the parties to choose arbitration is due to seat or place of arbitration. The place basically has an important role to play. The location of the arbitral seat is fundamental to defining the legal framework for international arbitral proceedings and can have profound legal and practical consequences in international arbitration. ${ }^{17}$ The influence of choosing the arbitral seat will create the possibility of the parties to act autonomically related to the arbitration agreement. In other words, it can be said that the essence of the arbitration agreement is to empower independent arbitrators to decide issues and disputes that may arise in the course of commercial damages. 18

Beside reason of seat or place of arbitration, some benefits of submitting of the dispute to arbitration are:

\subsubsection{Neutrality}

One of the most significant perceived advantages of arbitration is the neutrality of the arbitrator. The concept of neutrality is frequently used in the same sense as impartiality. Sometimes the term neutrality covers the notions of both independence and impartiality. However, using the term neutrality to refer to the impartiality or independence of arbitrators may cause confusion. In fact, the term neutrality technically has a different meaning. ${ }^{19}$

The term neutrality is often used in arbitration rules to refer to the nationality of arbitrators. An arbitrator is considered neutral if he has a nationality different from the

13 Burhing-Uhle is a writer of a book entitled Arbitration and Mediation in International Business.

14 Michael Pryler, Note 2, p116.

15 Jelena Hrle, Note 11, p10-11.

16 Jonanthan Hill, 2014, "Determining the Seat of an International Arbitration: Party Autonomy and the Interpretation of Arbitration Agreements", International and Comparative Law Quarterly, 63, p517-518.

17 See GB Born. International Arbitration: Law and Practice, Netherland: Kluwer Law International, 2012, p105.

18 See Andrew Barraclough and Jeff Waincymer, Mandatory Rules of Law in International Commercial Arbitration, p15.

19 Ana Carolina Pinto Cauri, Standards Impartiality, Independence, and Neutrality for Arbitrators in International Commercial Disputes, Canada: Published Heritage, 2004, p7. 
parties. Usually, in a tripartite panel, the third arbitrator is required to have a nationality other than the parties and he is usually designated as the neutral arbitrator. The same applies to the sole arbitrator when the tribunal is formed just by one arbitrator. ${ }^{20}$

In a broad sense, the term neutrality may also include notions of religion, economic ideology and social environment since these circumstances may affect the arbitrator's way of thinking. It should also include a juridical open-mindedness so as to embrace other countries' legal cultures and institutions and an absence of legal nationalism or parochialism. ${ }^{21}$

In this context, therefore, the neutrality of the arbitrator becomes a crucial issue in terms of international commercial disputes. As we known, the right to due process and to impartial arbitrators are a principle of international procedural public policy. If the arbitrator is biased or appeared to be biased, the recognition and the enforcement of the award may be denied. ${ }^{22}$

The Convention on Recognition and Enforcement of Foreign Arbitral Awards of 1958 the New York Convention - provides for the refusal of recognition and enforcement of an award by the competent authority when it is contrary to the public policy of the country where enforcement is sought. ${ }^{23}$ All jurisdictions allow vacation of arbitral awards when there is evidence of partiality of an arbitrator appointed as neutral.24

\subsubsection{Confidentiality}

Confidentiality procedure is also one of the most important reasons for parties choosing international arbitration. ${ }^{25}$ In this context, it can be seen in the case of John Forster Emmott \& Partners Ltd in which it was held that:

"case law over the last 20 years has established that there is an obligation, implied by law and arising out of the nature of arbitration, on both parties not to disclose or use for any other purpose any documents prepared for and used in the arbitration..." 26

Pursuant to the 2010 IBA rules, it expanded the rules regarding the confidentiality of the requested documents. It amended the confidentiality requirements include:27

a. The documents shall be kept confidential even if it is produced by non-parties in connection with arbitration;

b. Confidentiality requirements do not apply to documents that are in public domain;

c. Such documents shall only be used in connection with the arbitration;

d. The confidentiality requirements are qualified to the extent that the documents are required in order to fulfill a legal duty.

20 Ana Carolina Pinto Cauri, Note 19.

21 Doak Bishop \& Lucy Reed, 1998, "Practical Guidelines for Interviewing, Selecting and Challenging PartyAppointed Arbitrators in International Commercial Arbitration" Arbitration International Journal, 14, p402.

22 Ana Carolina Pinto Cauri, Note 19, p6.

23 Ana Carolina Pinto Cauri, Note 19, p6.

24 Elizabeth A. Murphy, 1996, “Standards of Arbitrator Impartiality: How Impartial Must they be?" Journal of Dispute Resolution, 2, p463.

25 Sameer Sattar, 2011, "Document Production and the 2010 IBA Rules on the Taking of Evidence in International Arbitration: a Commentary", Int. A.L.R., 216, p8.

26 Sameer Sattar, Note 25.

27 Sameer Sattar, Note 25, p8-9. 
Those requirements as expanded by the 2010 IBA rules can be seen in Esso Australia Resources Ltd v. The Honourable Sydney James Plowman. ${ }^{28}$ In this case, the Australian Court concluded that although confidentiality might arise in certain situations, the requirements were not absolute and the public's legitimate interest in obtaining information about the affairs of public authorities prevailed.

\subsubsection{Cost and Speed}

Cost and speed are generally very important in assessing a dispute resolution procedure. The parties have several opportunities in arbitration to take steps to control the length of the proceedings and its cost. The first opportunity is when they negotiate their commercial agreement. For example, they can provide in their arbitration agreement to have only one arbitrator and to agree on that arbitrator's qualifications. They can also agree to limit the number of depositions (if any) as well as the scope of discovery to highly relevant materials. ${ }^{29}$ In another word, arbitration can offer some opportunity for flexibility to reduce discovery of documents and pleadings; to impose strict time limits, and to dispense with a hearing and have arbitration on documents alone.

In the context of speed resolution, arbitration can easily be shorter than litigation in court because it has fewer rules and procedures than litigation and the rules and procedures it does have are more flexible. Arbitration is also not as formal as courtroom litigation and has few grounds for judicial review. By contrast, litigation is very formal and is bound by strict legal rules and procedural requirements that take more time to complete. There is also the possibility of numerous appeals of a court's final order that can make the litigation take more time, despite the best efforts to reform the judicial system. In many jurisdictions, appeals can add 10 years or more for a litigated case. ${ }^{30}$

\subsubsection{Recognition and Enforcement of Arbitral Award}

Arbitral awards are generally binding on the parties to the arbitrations. The statement can be found in some provisions in the New York Convention and The UNCITRAL Model Law. The New York Convention adopted by the United Nations Conference of International Commercial arbitration is intended to facilitate enforcement of foreign arbitral awards. It has achieved widespread international acceptance. It proceeds on the assumption that an award has been made and is concerned with the recognition and enforcement of foreign arbitral awards. ${ }^{31}$ The New York Convention has enjoyed widespread ratification, which further facilities the easy application of its provisions across virtue more than 149 countries. ${ }^{32}$

Article 1 (1) of the New York Convention states that the Convention applies to the recognition and enforcement of arbitral awards made in another country provided award is not considered a domestic award in the country where recognition and

28 Sameer Sattar, Note 25, p9.

29 Wolf Von Kumberg, 2011, “International Commercial Arbitration from a User's Perspective: Are the Benefit More Theoritical than Real?", Dispute Resolution Journal, 11, p 4.

30 Wolf Von Kumberg, Note 29, p5.

31 Wolf Von Kumberg, Note 29, p8. see also International Commercial Arbitration: Conventions and Moot Problems, UNSW, 2004, p1.

32 See New York Convention Countrie at http://www.newyorkconvention.org/new-york-conventioncountries. 
enforcement were sought. ${ }^{33}$ According to Albert Jan Van Dan Berg, under the New York Convention, parties an award do not necessarily have to be from different jurisdictions but can be from the same jurisdiction. ${ }^{34}$ However, while award that determines a dispute between domestic parties in a foreign country could be recognized and enforced pursuant to the New York Convention, in practice, most awards enforced pursuant to the New York Convention are international in nature. When parties were not forced to relitigate the merits of their disputes, national courts often subjected foreign arbitral awards to the same invasive scrutiny with they examined domestic awards. 35

As it is known that the New York Convention imposes two principal obligations on states parties. ${ }^{36}$ The obligation is to:

(1) Ensure that national courts, where appropriate, refer parties to arbitration and stay related judicial proceedings;

(2) Recognize and enforce arbitral awards essentially as if they were domestic judgments.

The UNCITRAL Model Law also arranges the matter of enforcement of arbitral awards. In this idea, it is important to state that an agreement made by the parties is binding and can be enforced at law. The court's jurisdiction to grant the stay will depend on which arbitration law regime applies to the arbitration agreement. ${ }^{37}$

The UNCITRAL Model Law in eight and its last chapter (its provisions) reflects the significant policy decision that the same rules should apply to arbitral awards whether made in the country of enforcement or abroad, and those rules should follow closely the 1958 New York Convention. This means that the UNCITRAL Model Law in the area of recognition and enforcement awards should refer to the New York Convention, particularly to those countries members.

\subsubsection{Grounds for Refusing Arbitral Awards}

The effect of ratification of the New York Convention conducted by parties states limit the grounds upon which a state can refuse to recognize a foreign arbitration award to the following circumstances: ${ }^{38}$

a. The agreement is invalid under the law (article V. 1 (a));

b. A party to the agreement suffers from incapacity (article V. 1 (a));

c. No proper notice of the arbitration was given (article V. 1 (b));

d. The award deals with a matter outside the terms of arbitration (article V. 1 (c));

e. The arbitration tribunal was not constituted in accordance with the agreement of the parties (article V. $1 \mathrm{~d}$ );

f. The subject matter of dispute is not capable of settlement by arbitration in that countries (article V. $1 \mathrm{~d}$ );

g. The award conflict with the public policy of the state where enforcement is requested (article V. 2 b).

33 Andrew Shields, 1998, "The Development of a Uniform Framework for International”, The Arbitrator, $1, \mathrm{p} 218$.

34 IAndrew Shields, Note 33.

35 Charles N. Brower and Jeremy K. Sharpe, Note 7, p648.

36 Charles N. Brower and Jeremy K. Sharpe, Note 7, p648.

37 The Australian Law Reform Commission, Note 1, p8.

38 John H. Willes and John A. Willes, Q.C., Note 9, p585-586. 
Apart from these grounds for refusal, states that have signed the New York Convention are obliged to recognize and therefore enforce foreign commercial foreign awards in the same manner as domestic awards. In states that are not signatories of the Convention, the arbitration award usually must be converted into a court judgment before it may be recognized and enforced. ${ }^{39}$ However, in some state practices, some countries need to arrange domestic rules although they have ratified the New York Convention, e.g. Indonesia.

The UNCITRAL Model Law itself arranges the idea of refusing arbitral awards. The UNCITRAL Model Law is identical to those listed in article V of the New York Convention. In this context, the enforcement of a foreign award may be refused, as followings: 40

a. Incapacity of a party to the arbitration agreement;

b. Invalidity of the arbitration agreement;

c. Lack of notice or inability to present a case;

d. Award outside submission;

e. The improper composition of arbitral authority or improper arbitral procedure;

f. The award has been set aside or is not yet binding;

g. Subject matter not arbitrable under the lex for; and

h. Enforcement contrary to public policy issues.

\subsubsection{Model Rules of Arbitration}

International arbitration is frequently conducted according to an established and welltested set of arbitral rules. ${ }^{41}$ The most significant international rules are those of the International Chamber of Commerce (ICC) and the United Nations Commission on International Trade Law (UNCITRAL). Both have been developed by the international organization and have been used on many occasions and therefore have an international currency and acceptability. ${ }^{42}$

ICC runs an arbitration service supervised by the ICC's International Court of Arbitration. The service provided by the ICC is that of a formal administrative body. The ICC does not conduct arbitration itself but administers arbitrations all over the world. ${ }^{43}$ An arbitration submitted to the ICC is run and heard by an arbitrator, subject to ICC rules. When parties cannot agree on the matter, these matters will be determined by the ICC. 44

The UNCITRAL Model Law is developed to provide a standardized and universal set of arbitral rules, suitable for use in any tribunal seeking to resolve a dispute irrespective of the national origin or status of the parties. ${ }^{45}$ The UNCITRAL Model Law is a comprehensive work governing the arbitration agreement, the composition and jurisdiction of the arbitral tribunal, the conduct of the arbitral proceedings and the making of and resource against the award.

\footnotetext{
39 John H. Willes and John A. Willes, Q.C., Note 9, p585-586.

40 The Australian Law Reform Commission, Note 1, p9.

41 The Australian Law Reform Commission, Note 1, p5.

42 Huala Adolf, The Basic Law of International Contract, Bandung: Refika Aditama, 2007, p179.

43 The Australian Law Reform Commission, Note 1, p2.

44 The Australian Law Reform Commission, Note 1, p2.

45 The Australian Law Reform Commission, Note 1, p5.
} 
Basically, parties to international commercial arbitration will arbitrate their dispute either in ad hoc arbitration tribunal or an arbitral institution. ${ }^{46}$ According to article 2 (a) the United Nations Commission on International Trade Law (UNCITRAL) Model Law, arbitration is stipulated as "any arbitration whether or not administered by a permanent arbitral institution. In the case of ad hoc arbitration, UNCITRAL has a United Nations General Assembly approved arbitration rules. According to Mohammad Naqib Ishan Jan and Abdulrashid Lawana Haruna,47 the rules are used in ad hoc arbitration if the arbitration tribunal is to conduct the arbitration by itself or the rules can be used in arbitration to be conducted in institutional arbitration centers. Some issues covered in the UNCITRAL rules such as the place of arbitration, appointment and numbers of arbitrators, the language to be used in the arbitration and content of the parties pleadings, interim measures, challenges to the jurisdiction of the tribunal, evidence, costs, and the effect to be given to the award of the tribunal. 48

\subsubsection{International Arbitration Institutions}

Various organizations and regimes, both government and private, have been established to provide a framework and a place for international commercial arbitration. The best known international arbitration organizations are the Paris-based International Chamber of Commerce (ICC), the World Bank's International Centre for the Settlement of Investment Disputes (ICSID), and the London Court of International (LCIA). There also many other arbitral bodies which supervise international arbitration, including those which are styled as national bodies such as Singapore International Arbitration Centre (SIAC) and the Singapore Institute of Arbitration, Hongkong International Arbitration Centre (HKIAC), China International Economic and Trade Arbitration Commission (CIETAC), Korea Commercial Arbitration Board, Japan Commercial Arbitration Association, Thai Arbitration Center, Kuala Lumpur Regional Centre for Arbitration, and Indonesian National Arbitration Association (BANI) and Indonesian Muamalat Arbitration Association (BAMUI) - has been changed to National Shariah Arbitration Council (Badan Arbitration Syariah Nasional - BASYARNAS).

The number of new cases registered in the year by the major arbitral institutions around the world shows that the number of those cases increase, ${ }^{49}$ such as:

1. ICC: from 593 in 2006 to 794 in 2010;

2. LCIA: from 137 in 2007 to 224 in 2011;

3. SCC50: from 141 in 2006 to 197 in 2010;

4. DIAC 51 : from 77 in 2007 to 186 in 2010;

5. SIAC: from 90 in 2006 to 198 in 2010;

6. HKIAC: from 394 in 2006 to 624 in 2010:

7. ICDR (AAA) 52: from 580 in 2005 to 888 in 2010.

46 Mohammad Naqib Ishan Jan and Abdulrashid Lawana Haruna, Note 6, p281.

47 Mohammad Naqib Ishan Jan and Abdulrashid Lawana Haruna, Note 6, p282.

48 See article 10-15 the UNCITRAL Model Law.

${ }^{49}$ Emmanuel Gaillard. 2012, "The Emerging System of International Arbitrations: Defining "System", ASIL Proceedings, 1, p289.

${ }^{50}$ The Stockholm Chamber of Commerce (SCC), available on its website at http:/ / www.sccinstitute.com.

51 The Dubai International Arbitration Center (DIAC), available on its website at http://www.diac.ae.

52 The International Center for Dispute Resolution, available on its website at http://adr.orge. 
Those of international arbitration institution has a convergence of arbitration laws and has institutional rules and practice of tribunals in international arbitration. ${ }^{3}$ The convergence of the rules of the various institution is signed through the adoption of the UNCITRAL Model Laws (arbitration rules). In Asia such as HKIAC, JCAA, and KCAB formulates their institutional rules premised on the UNCITRAL Model Laws (arbitration rules) with modification of the appointing bodies to cater for the operation of the relevant arbitral institution. ${ }^{54}$

The international arbitration institution basically also has a connection to the idea of "seat" and/or "place" of arbitration. They play an important role particularly in the idea of the seat of arbitration and place or arbitration. The term of "seat" and/or "place" put the position of the international organization to be applied by the parties of arbitration dispute to the process of arbitration in the case of arbitration. As an example of term, seat can be seen in the case of PT. Garuda Indonesia v. Birgen Air. The parties' arbitration agreement had expressly designated Indonesia as the seat of arbitration. ${ }^{55}$ It was subsequently agreed that, as a result of political unrest in Indonesia, Jakarta was an appropriate place for the arbitral hearings and that those hearings should be conducted in Singapore.56 The Singapore Court of Appeal held that Indonesia had remained the seat of arbitration throughout the arbitration. ${ }^{57}$ As a result, the Singapore courts do not have jurisdiction to entertain an application to have the award set aside under article 34 of the Model Law.

Basically, the term of "seat" and/or "place" practically has different meaning one to another. The UNCITRAL Model Law and some arbitration rules use the word "place", the term "seat" is used by the English Arbitration Act 1996 and also some arbitral institutions. 58 Term "seat" to some significant extent can be seen in Sumitomo case in which the idea of treating the physical location of an arbitration as necessarily its legal domicile. ${ }^{59}$ Another relevant case can be indicated also to Shashoua v Sharma case. This case showed the parties' agreement failed to refer to a seat or place of arbitration, but provided that the venue of arbitration shall be London, United Kingdom. ${ }^{60}$ The word 'seat' in Shashoua v Sharma case is a legal term of art, the word 'venue' is not. The word 'venue' do not indicate a choice of the seat or the place of arbitration. ${ }^{61}$ Indeed, Shashoua v Sharma case is different to PT. Garuda case in which the Singapore court contrasted 'the place of arbitration' with the venue of hearing. ${ }^{62}$

\section{Arbitration in the Islamic Law}

Arbitration - known as tahkim - in the Islamic Law actually only governs in the Family Law. Qur' an Surah An-Nisa verse 35 mention that "And if you fear dissension between the two, send an arbitrator from his people and an arbitrator from her people. If they both desire reconciliation, Allah will cause it to them. Indeed, Allah is ever Knowing and

\footnotetext{
53 Teresa Cheng, 2012, "Features of Arbitral Practice that Contribute to System Building", ASIL Proceedings, 1, p293.

54 Teresa Cheng, Note 53.

55 Jonanthan Hill, Note 16, p520.

56 Jonanthan Hill, Note 16, p520.

57 Jonanthan Hill, Note 16, p520.

58 Jonanthan Hill, Note 16, p519.

59 Jonanthan Hill, Note 16, p522.

60 Jonanthan Hill, Note 16, p522.

61 Jonanthan Hill, Note 16, p522.

62 Jonanthan Hill, Note 16, p523.
} 
Acquainted [with all things]". This verse is understood as an opportunity given by the Almighty Allah, SWT to solve the dispute like the family case without taking the case to the court. The limited scope of arbitration to dealing with the family matters is because the discussion of the arbitration can be found in fiqh ${ }^{63}$ and Sharia. ${ }^{64}$

In practice, arbitration had been done by the Prophet's companions, as experienced by Umar bin Khattab65, who being held bargaining the horse. Umar then rode the horse to test the condition of the horse. At the time of the test try, the horse suffered a broken leg, so that Umar intended to restore the horse to its owner. The owner horse was an objection and refused to receive back a horse that it had suffered a broken leg. Umar said, "Point out a thou believed to be Hakam66 between us". The owner of the horse said "I was willing Syuraih to be the Hakam. Both Umar and the owner of the horse agreed to submit the dispute to Syuriah. Syuraih then decided that Umar should pay the price of the horse. In his decision, Syuraih said to Umar: "Take what you have purchased and pay the price, or return it to its owner the horse as usual without no-flawing". ${ }^{67}$

In the context of the horse test case between Umar and the horse's Owner, Syuraih was basically "Hakam" appointed by the parties to settle the dispute rising between them. They then accepted the Hakam's decision to their case. ${ }^{68}$ The case clearly was a trade or a commerce case. It was not the family case as stipulated in the Qur'an Surah An-Nisa verse 35. According to Warkum Sumitro, 69 based on the case of Caliph Umar, it can be said that Tahkim is not only applied to the family matters, but also in business and politic laws. He stipulates further that the practice of Tahkim has been developed to cover all matters and also can be stated as the implementation of the Qur' an Surah An-Nisa verse 35.

Based on the discussion above, it can be said that the existence of Syuraih as a Hakam was a prove to describe the validity of Tahkim to settle the dispute..$^{70}$ Tahkim has been practiced in the era of the Prophet's companion, although it does not clearly mention about the dispute of commerce. It means that the Islamic Law itself can make an analogy to broad the scope of the Tahkim to cover the commerce matters and it is not against to the Islamic Law.

\section{Practices of Arbitration in Indonesia}

Indonesia became a party to the New York Convention following its accession on 7 October 1981. However, international foreign awards could not be enforced in Indonesia following its accession. ${ }^{71}$ The Supreme Court of Indonesia in its decision in 1984 held

63 Fiqh is an Arabic term tp draw Islamic Jurisprudence or the human understanding of the Sharia. Fiqh is dealing with the observance of rituals, moral, and social legislation in Islam.

${ }^{64}$ Sharia is beleived by Muslims to represent divine las as revealed in the Qur' an and Sunnah (the teaching and practices of the Islamic prophet Muhammad.

${ }^{65} \mathrm{He}$ was one of the most powerful and influential Muslim caliphs in history He was a senior Sahabi of the Islamic prophet $\underline{\text { Muhammad }}$ and succeeded $\underline{\mathrm{Abu} \text { Bakr }}(632-634)$ as the second caliph of the $\underline{\text { Rashidun }}$ Caliphate on 23 August 634.

66 Hakam is an Islamic term for arbitrator.

67 Satria Effendi, Arbitration in Sharia Law, Jakarta: BAMUI, 1994, p11.

68 Zainal Arifin, 2006, "Arbitration in Perspective of the Islamic Law”, HIMMAH, 18, (January -April), p75.

69 Warkum Sumitro, The Principle of the Islamic Banking and Relevant Institution, Jakarta: Raja Grafindo, 1996, p143.

70 Satria Effendi, Note 67, p11.

${ }^{71}$ Michael Pryler, Note 2, p76. 
that Indonesia court could not enforce foreign arbitral awards until the Government had promulgated implementing regulations to give the Convention effect.

Indonesia also has so far not yet concluded and treaty with other countries for the recognition and enforcement arbitral awards. Therefore, arbitral awards, as a rule, can not be recognized and enforced within the territory of Indonesia. ${ }^{72}$ The reason at that time referred to the article $436 \mathrm{RV}$ and the principle of territorial sovereignty.

In terms of the article $436 \mathrm{Rv}$, it stated that with the exception of article 724 Commercial Code and other provisions, foreign judgments handed down by judges or courts of foreign countries cannot be enforced in Indonesia. In addition, the tendency to do not enforce foreign judgments in the sense of the principle of territorial sovereignty is because basically the foreign judgments cannot be automatically enforced in the territory of another state. ${ }^{73}$ However, after Indonesia enacted the Law No. 30 year 1999 concerning Arbitration and Dispute Settlements, the foreign arbitral awards can be merely recognized and enforced in Indonesian court, if: ${ }^{74}$

a. The awards should be conducted by a state that has a treaty about recognition and enforcement international foreign awards with Indonesia either bilateral or multilateral treaty;

b. The awards are limited to the scope of trade law under Indonesian regulations;

c. The awards can be only enforced as long as it is not against public policy;

d. The awards can be conducted in Indonesia after filing exequator letter from the chief of the Central Jakarta District Court;

e. The awards, in which one of the parties is Indonesian citizens can be enforced in Indonesia after filing exequator letter from the Supreme Court, then the Supreme Court attributes to the Central Jakarta District Court.

Some cases that show Indonesia (Indonesian companies) as a party such as Pertamina vs. Lirik case ${ }^{75}$, PT. Istana Noodle House vs PT Plaza Indonesia Realty, Tbk.,76 PT. Garuda Indonesia vs. Birgen Air Singapore77, Amco Asia Corporation vs Indonesia (Kartika Plaza hotel) ${ }^{78}$, etc. Those cases do emphasise the position of the parties in the context private vs private. On this situation, there is no problem to deal with the cases. However, when one of the parties is the government, it means that it would be public vs private. In the context international arbitration dispute, the government must decide when it is acting as a private or a public. The government must agree that its position in contract - when there is dispute - is private. It is because its authority derives from the consents of the disputing parties, mutually given in the context of a reciprocal relationship between juridical equals, both acting in a private capacity.

To support practices of arbitration in Indonesia, Indonesian also has its Arbitration Institution - called Indonesia National Board of Arbitration (hereinafter Badan Arbitrasi

72 Sudargo Gautama, The Commercial Laws of Indonesia, Bandung, PT. Citra Aditya Bakti, 2001, p49-50.

73 Sudargo Gautama, Note 72, p51.

74 Joni Emerzon, Alternative Dispute Settlement out of Litigation, Jakarta, PT. Gramedia Pustaka Utama, 2001, p115-116.

75 National Legal Reform Program (NLRP), 2010, “The Pertamina_Lirik Case: The Enforcement of International Arbitration Awards", Quarterly Fact Sheet, 3rd QFS, p7 and p49.

76 O.C. Kaligis, Fairness Principle in Arbitration, Bandung: PT. Alumni, 2009, p1-5.

77 Huala Adolf, Note 42, p167.

78 Huala Adolf, International Economic Law, Jakarta: PT. RajaGrafindo Persada, 2005, p.133. The case was referred by the parties to ICSID because of the revocation of a foreign investment license between the Republic of Indonesia and an American company and other countries having their legal seat in Hongkong. 
Nasional Indonesia - BANI) and Indonesia Muamalat Board of Arbitration (hereinafter Badan Arbitrasi Muamalat Indonesia - BAMUI).

BANI was established in 1977 on initiative of 3 (three) prominent lawyers, namely Subekti, Haryono Tjitrosoebno, and Priyatna Abdulrasyid. ${ }^{79}$ The center is located in Jakarta with some offices in some Indonesia major cities including Surabaya, Bandung, Pontianak, Denpasar, Medan, Palembang, dan Batam. The purpose of establishment of BANI is:

a. To provide a range of service in relation to arbitration, mediation, binding opinion, and another form of dispute resolutions. ${ }^{80}$

b. To participate in the law enforcement process in Indonesia through the application of arbitration and alternative dispute resolution for resolving disputes in various sectors of trade, industry, and finance. ${ }^{81}$

c. To carry out studies and research and trading/education program pertaining to arbitration and alternative dispute resolution. ${ }^{82}$

BAMUI was established in 1993 on initiated by Indonesia Ulama Council (Majelis Ulama Indonesia - MUI). MUI at that time was represented by Hasan Basri and H.S. Prodjokusumo. The name of BAMUI then has been replaced to be National Shariah Arbitration Council (hereinafter Badan Arbitration Syariah Nasional - BASYARNAS) on 24 December 2003.83 The purpose of the establishment of BASYARNAS is not only for the sake of awareness and interest of Islamic people, but also it is for the sake of economic and financial necessity in Indonesia generally.

BASYARNAS is an arbitral institution that is neutral and independent. Its existence plays an important role in dealing with Islamic business disputes. BASYARNAS is located in Jakarta with some offices in some Indonesia major cities. The opening of BASYARNAS Offices is accordance with the MUI in provincial level. Even though the number of arbitration cases is a few, BASYARNAS is still needed to cover the Islamic business disputes, particular in the future. The indication of it can be seen through the number of Islamic Products related to Bank activities such as Mandiri Shariah Bank, Shariah BNI, Shariah BTN, and others. ${ }^{84}$

\section{Conclusion}

Arbitration is a form of alternative dispute resolution where the parties, usually to a contract, agree to have a dispute heard before a private arbitration forum and finally decided by a single arbitrator or panel of arbitrators instead of going to court to have their dispute heard publicly and decided by a judge and/or jury. The reason why the parties to choose arbitration are due to the place of arbitration; neutrality; confidentiality; cost and speed; recognition and enforcement awards; grounds for refusal arbitral award; model rules of arbitration; and international arbitration institution. Arbitration in practice might see the position of the parties whether they are private vs private or public vs private. In Indonesia practice, most of the cases took place such as Pertamina vs. Lirik

79 BANI, (accessed 21 December 2015), http:/ / baniarbitratiion .org. see also Huala Adolf, The Basic Rule of International Contract Law, Bandung: Refika Aditama, 2010, p202.

${ }^{80}$ Huala Adolf, Note 79.

81 Huala Adolf, Note 79, p202.

82 Huala Adolf, Note 79, p203.

83 See http://mui.or.id. (accessed 15 December 2015).

84 Ibid. 
case, PT. Istana Noodle House vs PT Plaza Indonesia Realty, Tbk., PT. Garuda Indonesia vs. Birgen Air Singapore, and Amco Asia Corporation vs Indonesia (Kartika Plaza hotel).

In the Islamic law itself, arbitration is called as Tahkim. In prior, the area of Tahkim basically is only to the family matters. However, the case of the horse riding between the Caliph of Umar bin Khattab and the Owner of the horse shows the broad of Tahkim to not only the family matters but also the commerce matters. The basic regulation is Qur'an Surah An-Nisa verse 35.

\section{References}

Books:

A. Cavanna. 1979. History of Modern Law in Europe, Milan.

Abdurrasyid, Priyatna. 2002. Arbitration and Alternative Dispute Settlements, Jakarta, Fikahati Aneska.

Adolf, Huala. 2010. The Basic Rule of International Contract Law, Bandung: Refika Aditama. Adolf, Huala. 2007. The Basic Law of International Contract, Bandung: Refika Aditama. Adolf, Huala. 2003. International Economic Law, Jakarta: PT. RajaGrafindo Persada.

Carolina Pinto Cauri, Ana. 2004. Standards Impartiality, Independence, and Neutrality for Arbitrators in International Commercial Disputes, Canada: Published Heritage.

DM. Lew, Julian. 1978. Applicable Law in International Commercial Arbitration, Netherlands: Sijthoff and Noordhoff.

Effendi, Satria, 1994. Arbitration in Sharia Law, Jakarta: BAMUI.

Emerzon, Joni. 2001. Alternative Dispute Settlement out of Litigation, Jakarta: PT. Gramedia Pustaka Utama.

GB Born, 2012. International Arbitration: Law and Practice, Netherland: Kluwer Law International.

Gautama, Sudargo. 2001. The Commercial Laws of Indonesia, Bandung: PT. Citra Aditya Bakti.

H. Willes, John. and John A. Willes, Q.C., 2005. International Business Law: Environments and Transactions, Singapore: McGraw-Hill International Edition.

Jelena Hrle, 1999, International Arbitration and Competition Law, Thesis, Faculty of Law, Canada: McGill University.

O.C. Kaligis, 2009. Fairness Principle in Arbitration, Bandung: PT. Alumni.

Pryles, Michael. 1997. Assesing Dispute Resolutin Prosedures, Course Materials of International Commercial Arbitration, Australia: UNSW - Sydney.

Rubino-Sammartono, Mauro. 2010, International Arbitration: Law, and Arbitration, Netherland: Kluwer Law International.

Warkum Sumitro, 1996. The Principle of the Islamic Banking and Relevant Institution, Jakarta: Raja Grafindo.

Journals:

Ali Radhi, Hassan. 1992. "State Courts and Arbitration in the Gulf Cooperation Councils (GCC) Countries", ICC Int'l Ct. Arb. Bull, 57 (5).

Arifin, Zainal, 2006. "Arbitration in Perspective of the Islamic Law", HIMMAH, VII (18). Bishop, Doak \& Lucy Reed. 1998. "Practical Guidelines for Interviewing, Selecting and Challenging Party-Appointed Arbitrators in International Commercial Arbitration" Arbitration International Journal, 14. 
Cheng, Teresa. 2012. "Features of Arbitral Practice That Contribute to System Building", ASIL Proceedings, 2012).

Gaillard, Emmanuel. (2012). “The Emerging System of International Arbitrations: Defining "System", ASIL Proceedings.

Ishan Jan, Mohammad Naqib and Abdulrashid Lawana Haruna, 2014. "the Role of Arbitration in the Resolution of Internationa Commercial Disputes", IIUM Law Journal, 22 (2).

Jonanthan Hill, 2014. "Determining the Seat of an International Arbitration: Party Autonomy and the Interpretation of Arbitration Agreements", International and Comparative Law Quarterly, 63.

National Legal Reform Program (NLRP), 2010. “The Pertamina_Lirik Case: The Enforcement of International Arbitration Awards", Quarterly Fact Sheet, $3^{\text {rd }}$ QFS.

N. Brower, Charles. and Jeremy K. Sharpe.2003. "International Arbitration and the Islamic World: the Third Phase", the American of International Law, 97.

Sattar, Sameer. 2011. "Document Production and the 2010 IBA Rules on the Taking of Evidence in International Arbitration: a Commentary", Int. A.L.R. 216.

Shields, Andrew. 1998. The Development of a Uniform Framework for International, The Arbitrator.

The Australian Law Reform Commission, 1999.“International Arbitration”, ALRC. 80.

Von Kumberg, Wolf. 2011. "International Commercial Arbitration from a User's Perspective: Are the Benefit More Theoritical than Real?", Dispute Resolution Journal, November.

\section{Conflict of Interest Statement:}

The author(s) declares that the research was conducted in the absence of any commercial or financial relationships that could be construed as a potential conflict of interest.

Copyright $(2019$ HALREV. All rights reserved. 